\title{
Književnost i revolucija kao nasljeđe avangarde. Tribina na Filozofskom fakultetu u Zagrebu
}

\begin{abstract}
Protrka Štimec Marina, Književnost i revolucija kao naslijeđe avangarde. Tribina na Filozofskom fakultetu u Zagrebu (Literature and Revolution as an Avant-garde Heritage. Round Table on the Faculty of Humanities and Social Sciences in Zagreb). "Poznańskie Studia Slawistyczne" 18. Poznań 2020. Publishing House of the Poznań Society for the Advancement of the Arts and Sciences, Adam Mickiewicz University, pp. 321-326. ISSN 2084-3011.

The text summarizes and reviews the round table organized on the $19^{\text {th }}$ September 2019 at the Faculty of Humanities and Social Sciences in Zagreb with the main goal to investigate the methodological and thematic approaches to the avant-garde related to the concept of revolution. The scientists from Zagreb and Belgrade, Tatjana Jukić, Predrag Brebanović, Danijela Lugarić and Branislav Oblučar, presented their contributions to debate around the above-mentioned themes. Literature as well as revolution were examined in the theoretical and historical context of the avant-garde. Public debate showed that these issues have been still sparking vivid interest in the academic, artistic and intellectual world. The round table was organized as part of the project Literary Revolutions established by the Croatian science foundation 2018-017020.
\end{abstract}

KEYwords: avant-garde; literature; revolution; round table; Zagreb

Odnos književnosti i revolucije kroz povijest upućuje na najširi odnos društvenog i kulturnog polja, odnosno na složene i divergentne silnice koje se razvijaju između političkih i umjetničkih praksi. Veza između romantizma te Francuske i Američke revolucije ili avangarde i Oktobarske revolucije eksplicira ove odnose tako da na konkretniji način upućuje na spoj umjetnosti i života - o čemu je pisao već Friedrich Schlegel u znamenitom 116. fragmentu Athenauma, u kojem romantičarski pokret karakterizira kao „progresivan i univerzalan“, usmjeren ne samo tako da spaja poetske žanrove, dovodeći poeziju u kontakt s filozofijom i retorikom, nego spaja i poeziju i prozu, genijalnost i kritiku, poeziju umjetnosti s poezijom 
prirode, čime dovodi do toga da poeziju učini živućom, a društvo i život poetskim. Pitanje autentičnosti, odnosno originalnosti ili, u hrvatskoj književnosti 19. stoljeća, izvornosti umjetnosti, jezika i života od tog vremena postaje jednim od ishodišnih točki stvaranja i recepcije književnosti. Spajanje života i umjetnosti u ovom je vremenu odredilo i nastanak umjetničkih formi društvenog života poput boeme i niza drugih prepoznatljivih „umjetničkih“ stilova u javnom ophođenju. Još šire od toga, ovaj je impuls utjecao i na stvaranje i disperziju različitih pokreta i umjetničkih praksi koje su, u avangardno doba, bučno i snažno stasale, promptno djelovale i brzo se gasile. Književni časopisi ovog razdoblja često su poduhvat pojedinaca ili manje skupine koja izražava svoju razliku u odnosu na dominantnu matricu koja usmjerava umjetničke i društvene prakse.

Avangardni stilovi i smjerovi u odnosu prema konceptu revolucije i revolucionarnog otvaraju prostor i za razumijevanje ne samo povijesno ograničenih fenomena (Bürger), nego su utjecali i na, kako je pokazao Renato Poggioli, transhistorijski koncept avangarde u kojem se revolucija može razumjeti i kao koncept inherentan umjetnosti, odnosno književnosti. Ovoj su se temi u dugom periodu trajanja i proučavanja na različite načine vraćali istraživači u Zagrebu - Aleksandar Flaker, Dubravka Oraić-Tolić, Dubravka Ugrešić i drugi - okupljeni oko objavljenih devet Pojmovnika ruske avangarde, uz jedan pripremni - nulti iz temata Umjetnost riječi iz 1981. godine. Uzimajući u obzir njihova kao i pojedinačna istraživanja i publikacije autora poput Gordane Slabinac, Mladena Machieda, Cvjetka Milanje, Nikole Ivanišina, Zorana Kravara, Žive Benčić, Sanjina Sorela, Slavena Jurića i drugih teorijskih i književnopovijesnih publikacija objavljenih u Hrvatskoj, Jugoslaviji i Europi tog vremena - pokrenuli smo znanstveni projekt pod naslovom Književne revolucije koji je 2018., na rok od četiri godine, odobrila i financira Hrvatska zaklada za znanost. Uz voditeljicu projekta, prof. dr. Marinu Protrka Štimec s Filozofskog fakulteta u Zagrebu, istraživački tim čine prof. dr. Aleksandar Mijatović s Filozofskog fakulteta u Rijeci, doc. dr. Zrinka Božić Blanuša, doc. dr. Andrea Milanko, dr. sc. Ana Tomljenović i doktorandi Zvonimir Glavaš i Mirela Dakić, svi sa zagrebačkog Filozofskog fakulteta. Cilj projekta je evidentirati smjerove i rezultate dosadašnjih istraživanja avangarde, posebno kroz aspekt revolucionarnog, te rasvijetliti pitanja i teme koje se u suvremenim pristupima pokazuju nezaobilaznima. Naime, recentni interes istraživača 
za književnosti inherentnim strategijama i emancipatornim praksama upućuje istovremeno prema njezinim historijskim i teorijskim okvirima. Projekt će stoga ponuditi okvir za razumijevanje temeljnih pojmova i tema, nudeći modele, tipove, nove interpretacije i revalorizacije temeljnih književnih tekstova i autorskih opusa.

U sklopu prve faze istraživanja ovih tema na Filozofskom fakultetu u Zagrebu je 19. rujna 2019. godine održana tribina pod naslovom Književnost i revolucija. Nasljeđe avangarde u hrvatskoj književnosti. Cilj tribine bio je da se uz pomoć istraživača koji su se posljednjih desetljeća sustavno bavili ovom i srodnim temama te u dijalogu sa zainteresiranom znanstvenom i stručnom javnosti sondiraju ključna mjesta i smjerovi novih pristupa. Na tribini su sudjelovali prof. dr. Tatjana Jukić s Filozofskog fakulteta u Zagrebu, izv. prof. dr. Predrag Brebanović s Filološkog fakulteta u Beogradu, doc. dr. Danijela Lugarić i doc. dr. Branislav Oblučar sa zagrebačkog Filozofskog fakulteta.

Danijela Lugarić je na tribini govorila kao istraživačica i urednica zbornika o Oktobarskoj revoluciji te kao predstojnica Zavoda za književnost koji je motivirao znanstvene skupove i istraživanja kasnije objavljivana u Pojmovnicima ruske avangarde. U svom je izlaganju ponudila dijakronijski presjek istraživanja avangarde u odnosu prema konceptu revolucije - od nultog Pojmovnika pa sve do posljednjeg, za koji se ispostavilo da nije deveti, objavljen 1993., nego deseti koji je posve pripremljen za tisak pronašla u arhivi Zavoda. U izlaganju je također pokazala da je sam žanr pojmovnika odabran upravo zbog svoje sličnosti s prvotnom zadanom koncepcijom pojma avangarde, koja je prije svega vodila računa o strukturi tekstova i definiranju temeljnih pojmova kojima će se projekt baviti. Pojmovnik ruske avangarde, koji je kasnije prerastao u današnji Zagrebački pojmovnik kulture, kako je pokazala Danijela Lugarić, u nultom broju avangardu predstavlja kao umjetnički pokret čija je snaga bila upravo u tome da upozori na anomalije u okruženju i estetskim ih sredstvima učini vidljivima. U još neobjavljenom, desetom svesku avangarda kao predmet istraživanja postaje svojevrsnom anomalijom. Time je, kako ističe, pozivajući se na pojmovničare, i sama doživjela sudbinu pojmova kojima se bavila: na vidjelo izlazi njezin „sadistički sindrom“ (Igor Smirnov) pri čemu, kako ističe Aage Hansen-Löve, doživljava poraz zbog svoje hermetičnosti. Lugarić zaključno naglašava kako avangardu zbog toga treba promatrati 
kroz korelaciju s drugim umjetničkim izrazima i pravcima, „kroz neutralizaciju egzotičnosti njezina društveno-kulturnog položaja“, a ne iz implicirane umjetničke samosvijesti i autonomije.

Autor instruktivne recentne Avangarde krležijane, podnaslovljene kao Pismo ne o avangardi (2016), Predrag Brebanović se u svom izlaganju usmjerio na stilsko-tipološki pristup avangardi, ostavljajući po strani historijsko-tipološki, kako ih je nazvao, slijedeći analognu distinkciju iz knjige Priroda kritike Svetozara Petrovića, pri čemu je prvu povezao s pristupom Renata Poggiolija, a drugu s tumačenjima Petera Bürgera. U svom tumačenju se oslonio na tezu Dubravke Oraić-Tolić da se povijest avangarde može promatrati u kretanju od estetike preko politike ka filozofiji. U skladu s time povijesna avangarda bi bila (anti)estetski projekt koji 30-ih godina XX. stoljeća ulazi u političku fazu nakon koje slijedi, uvjetno rečeno, filozofska. Pri tome Brebanović upućuje na teorijske rasprave koje se tiču tumačenja avangarde nakon 1989. (Boris Groys, Hal Foster, Inke Arns), na ideju o nastavljivosti avangarde i ono što je posebno zanimljivo, na mjesto koje pritom ima jugoslavenska avangarda u različitim oblicima. Niz novih pojmova - od postavangarde, retroavangarde, retroutopije i tako dalje kako je istaknuo, svoje značenje formiraju u jugoslavenskom kontekstu. Polazeći od te konstatacije protumačio je i Krležinu Hrvatsku književnu laž i sukob na književnoj ljevici, usporedivši ga s analognim sukobima u Rusiji i Francuskoj. Osvrnuo se također na zenitizam kao na rubni fenomen te na nove pristupe i suradnje koje su se pojavile zadnjih godina i rezultirale zanimljivim projektima: dva znanstvena skupa o Ujeviću - u Zagrebu i Beogradu, bilateralni projekt koji vodi zajedno s kolegom Tomislavom Brlekom iz Zagreba, skupovi o Krleži u Leksikografskom zavodu i na Festivalu jednog pisca u Beogradu te projekt Zaklade, Književne revolucije. Povratak povijesnim temama koje je generirala avangarda u tom smislu vidi kao mogućnost da se sagleda avangardno u suvremenom društvu, kulturi i umjetnosti.

Branislav Oblučar u nastavku polazi od spomenutih koncepata u pristupima avangardi nudeći jasniju skicu pojma i prakse avangarde nakon Drugog svjetskog rata. Primjere iz hrvatske književnosti, Radovana Ivšića, Boru Pavlovića, Zvonimira Mrkonjića, pritom povezuje s nekim nadrealističkim postulatima te nekim analognim praksama. Polazeći od časopisa Oko preko Offa do postmodernih praksi, poezija iskustva jezika, odnosno 
semantičkog konkretizma (Branko Maleš, Branko Čegec), Oblučar, kako se vidi u članku koji objavljuje u ovome broju Poznanjskih slavističkih studija, upućuje na složenu vezu između historijskog i ahistorijskog u avangardi, kao i na činjenicu da se u pristupima ovim temama treba voditi računa o kontinuitetu praksi prijeloma i diskontinuiteta. Njegov zaključak, slično Brebanovićevu, usmjerava istraživački fokus na pomna čitanja autorskih tekstova, ali u poziciji prema nadnacionalnom, jugoslavenskom kontekstu.

Tribinu je zaključila Tatjana Jukić pitajući se možemo li nakon 1989. godine govoriti o modernizmu ili o ubrzanom usvajanju predmodernih aparata i procedura. Ako modernost, odnosno avangarda kao fundamentalno moderna ideja, može samu sebe razumjeti upravo kroz književnosti (Jukić se pri tom poziva na Waltera Benjamina i Carla Schmitta), onda se i revolucije, kao transformacije misli o transformativnom, sagledavaju kroz konkretna književna ostvarenja. Hamlet bi tako, prema Schmittu, bio prva faza Engleske revolucije, korespondirajući s političkom teorijom Johna Lockea, Thomasa Hobbesa i škotske filozofije u 18. stoljeću. Tezu je moguće naći i kod Matthewa Arnolda, koji povezuje Shakespearea i Englesku revoluciju, a Jukić na sličan način dovodi u vezu avangardu i Oktobarsku revoluciju, smatrajući da se i 1989. i kolaps socijalizma može sagledati kao dovršetak modernog projekta. U zaključku se nadovezala na esej Jean-Luca Nancyja Lenjin i elektricitet (2017), objavljen povodom stote obljetnice Oktobarske revolucije, u kojem Nancy postavlja tezu da se moderna misao iscrpila u času kad je Lenjinova politička zamisao o elektrifikaciji ustupila mjesto teologizaciji tehnologije, pa smo danas skloni pripisivati tehnologijama teološku dimenziju. Njegovo pitanje o mogućnosti zajednice bez bogova i bez tehnologije koja je zauzela njihovo mjesto Tatjana Jukić postavlja u okvir starogrčkog shvaćanja tragedije kod Euripida i Aristotela, upućujući time na reperkusije koje njihov rasplet ima u današnjem vremenu.

Usmjeravajući raspravu, Zvonimir Glavaš, moderator tribine, a kao odgovor na poticajne teze završnog izlaganja, navodi Rancièreova Imena historije u kojima autor ističe kako je važno da historija ne apsorbira potencijal revolucije - što za njega znači da se čuva otvorenost brana jeziku, simboličkoj produkciji, simbolizaciji, izmještanju, iščašivanju govora s onih mjesta na kojima je on bio ili im je pripadao. Drugim riječima, prema 
avangardnim određivanjima književnosti literarnost bi bila taj govor koji je izglobljen, izmješten iz svog ,prirodnog“ zakonitog mjesta. U raspravi je Jukić označila 19. stoljeće kao stoljeće književnosti, dok je 20., zajedno s avangardom vezala uz film. Maša Kolanović je uputila na vezu između znanstvenog angažmana i interesa za avangardu kod Dubravke Ugrešić i njezina književnog i društvenog angažmana, što je dovelo do problematizacije odnosa suvremenih istraživača prema „očevima“ - najviše prema spominjanom Aleksandru Flakeru. Rasprava se dotaknula i književnopovijesnih odnosa, Krleže, sukoba na književnoj ljevici, statusa Koče Popovića i Marka Ristića te subverzivnog i društvenog angažmana suvremene književnosti - na što je uputio student Bruno Sokolić. Zaključak rasprave je bio usmjeren prema međudjelovanju teorijskih pristupa i književne prakse u odnosu prema društvenom angažmanu i emancipatorskom potencijalu književnosti, primjerice u praksama časopisa Pro Femina.

Organizatori i sudionici su bili zadovoljni prilozima, dijalogom i raspravom koja će sa svim zaključcima i pitanjima postati integralan dio sljedeće faze istraživanja na projektu. Nastavak rada usmjeren je prema razvijanju temeljnih znanja, teorijskih i metodoloških, koji će iz suvremenih pristupa omogućiti razumijevanje i analizu koncepata književnih revolucija utemeljenih u estetskoj autonomiji književnosti. U njima će biti važno identificirati pretpostavke koje su omogućile avangardnu književnu revoluciju te opisati tekstualnu mrežu simboličkih i političkih praksi koje zajednički tvore revolucionarni, emancipatorski potencijal književnosti na kojem su se u više navrata zadržali i govornici i slušatelji tribine. Sve aktivnosti projekta mogu se pratiti na internetskoj stranici: lire. ffzg.unizg.hr, a snimka tribine je dostupna na: https://www.facebook. com/114034199985141/videos/704723586679309/. 